\title{
Osmanlı'nın Son Yıllarında Kadın Eğitimine Yönelik Önemli Bir Kitap: Kadınlara Amelî Sanayi-i Ziraiye Dersleri
}

An Important Book on Women's Education in the Last Period of the Ottoman Empire: Practical Agro-industry Lessons for Women

\section{Mehmet BİLİR}

Tarım ve Orman Bakanlığı Eğitim ve Yayın Dairesi Başkanlığı, Ankara

mehmet.bilir@tarimorman.gov.tr

0000-0003-1659-4483

Gönderilme Tarihi: Kabul Tarihi

5 Ekim 2020

22 Ocak 2021

\section{ÖZET}

Osmanlı'dan günümüze, kadınlara yönelik dersler ev ekonomisi disiplini altında verilmektedir. Osmanlı Devleti'nin aslında bir yazı ve kayıt medeniyeti olduğunu bilmekle birlikte, gerek bilgi kaynaklarının kaybolması ve gerekse Osmanlı Türkçesi (Osmanlıca) okuyanların az olması sebebiyle geçmişe dair bilgilerimiz yetersiz kalmaktadır. Günümüzde Osmanlıca kurslarının yaygınlaşması, ortaöğretimde bile seçmeli ders olarak okutulması, bu tarz bilgilerin farkındalığını artırmakta, erişimi kolaylaştırmaktadır. Tarım ve Orman Bakanlığg Kütüphanesi’nde yer alan ve 1915'li yıllarda basılmış olan “Kadınlara Amelî Sanayi-i Ziraiye Dersleri” isimli kitap, ev idaresi ve ziraat sanatlarına ait bazı konuları içermesi açısından önem arzetmekle birlikte asıl onu önemli kılan, bu kitabın kadınlara yönelik olduğunun özellikle vurgulanmış olmasıdır. Kitabın tanıtımı, içindeki bazı bilgilerin detaylı ve günümüz diliyle yazılmasıyla birlikte, özellikle un ve ekmek üzerine çalışan, geleneksel üretimle ilgilenen araştırıcıların da dikkatine sunulmakta ve bazı bilgilerin bugünle kıyaslanması amaçlanmaktadır. 
mekçilik, nişastacılık, gülyağı, gülyağcılık

\section{ABSTRACT}

Lessons for women have been given under the discipline of home economics since the Ottoman times. Although we know that the Ottoman Empire is a civilization of writing and recording, our knowledge of the past is insufficient due to the loss of information sources and the limited number of Ottoman language readers. Today, the widespread use of Ottoman language courses and the fact that the lessons are taught as an elective course even in secondary education increase the awareness of such information and facilitate access to the sources. This book, which we came across in the Library of the Ministry of Agriculture and Forestry and was published in 1915, is important in terms of including some topics related to home economics and agricultural arts, but what makes it really important is that it is specifically intended for women. The introduction of the book is brought to the attention of researchers who are interested in traditional production, especially flour and bread, together with some of the information in it written in detail and in today's language, and it is aimed to compare some information with today.

KEYWORDS: Woman, Ottoman period, bakery, starch, rose oil, production of rose oil

\section{GíRiş̧}

İnancımızda ve kültürümüzde kadın, toplumun en küçük yapısını oluşturan ailenin ve evin temel direğidir. Evin temizlik, barınma, beslenme gibi temel ihtiyaçlarını karşılamasının yanında eşin yoldaşı, zaman zaman terapisti, çocukların annesi ve ilk öğretmeni, çocuklar büyüdüklerinde ise danışmanları görevlerini üstlenmişlerdir. Türklerde binlerce yıldır hanenin, obanın kararını analar vermiş, dinimiz İslam ise "Cennet, anaların ayaklarının altındadır." Hadis-i Şerifi ile kadının çıkabileceği en yüce mertebeyi belirtmiştir. Anadolu'nun safi diliyle merhum Neşet Ertaş; "Kadın, insandır; bizler ise insanoğlu." ifadesi ile, bu yüceliği söylenebilecek en yalın ifade ile dile getirmiştir.

Tunç Yaşar (2019) ev idaresini "bilimsel bir alan olarak ev hayatına ve daha özelde gündelik ev rutini içerisinde kabul edilen ev işlerine bilimsel ve pedagojik standartlar belirlemekte ve bu şekilde evde üretkenliği ve verimliliği arttırmayı hedeflemek" şeklinde tanımlamıştır. Geleneklerimizin de etkisi ile, son zamanlarda kadınların iş hayatında daha fazla yer alması sebebiyle değişmeler olmasına rağmen, toplumumuzda ev idaresi kadınların görevi olarak kabul edilegelmiştir.

Osmanlı K1z Mekteplerinde ev idaresini incelediği eserde Osmanlı döneminde ev idaresinden bahisle şunları bildirmektedir: "On dokuzuncu yüzyılın ikinci yarısından itibaren kitaplar ve süreli yayınlarda müstakil bir alan olarak ele alınmakta ve kız mekteplerinde ders olarak okutulmaktadır. Ev hayatının belirli standartlarda disipline edilmesi ve rasyonelleştirilmesi anlayışı çerçevesinde evin düzeni, fiziksel koşulları, hij- 
yen, evde sağlık, ısınma, kıyafetlerin düzeni ve temizliği, çocukların bakımı ve terbiyesi, yemek, sofra düzeni, âdâb-1 muâşeret gibi ev ile ilgili olabilecek her türlü konu ev idaresi başlığı altında incelenmekte ve geleneksel Osmanlı ev idaresi birçok açıdan eleştirilmektedir.” Dünyadaki özgürlükçü değişimlerle beraber, geleneksel değerleri yıkmadan bu değişimlere toplumsal açıdan ayak uydurabilmek kolay olmayacaktır (Tunç Yaşar, 2019).

Altın (2019) Osmanlı eğitim tarihinde Dârülmuallimatı anlattığı eserinde, 1869 Maarif-i Umumîye Nizamnamesinde, sıbyan ve rüşdîye olmak üzere iki şube ve her şubenin de kendi arasında, Müslüman ve gayr-1 müslimlere mahsus olmak üzere iki sınıf halinde teşkil edildiğini, sıbyan şubesinin öğrenim süresinin 2, rüşdiye şubesinin öğrenim süresinin 3 yıl olduğunu, İstanbul dışından getirilen kızların yatılı olarak okuyacakları, Dârülmuallimatı bitirdikten sonra memleketlerine öğretmen olarak gidecekleri şekilde eğitim gördüklerini bildirmektedir.

Birinci Dünya Savaşı yıllarında Darülmuallimât sayısı vilayetlerde on bire ulaşmıştır. Osmanlı Devleti'nin sonunda vilayetlerde sadece beş Darülmuallimât varlığını devam ettirerek Cumhuriyet dönemine ulaşmıştır (Aksoy, 2017).

Dârülmuallimât-1 İbtidâîye'de ziraatle ilgili ilk ders olan "Sanayi-i Zirâiye ve Bahçıvanlık" dersi, ilk defa 1914-1915 tarihli Dârülmuallimât Programı'na girmiş, dört ve beşinci sınıflarda birer saat olarak okutulması kararlaştırılmıştır (Şanal, 2004).
Sanayi-i Ziraiyye ve Bahçıvanlık dersi genel olarak hayvancılık ve bitki (sebze) yetiştirme üzerine inşa edilmiştir. Kümes hayvanlarının bakımı, süt ineğinin bakımı ve elde edilen sütle yapılabilecek süt ürünleri öğretilmiştir. Etin pişirilmesi ve muhafaza edilmesine yönelik bilgilendirmeler yapılmıştır. Ailenin ihtiyaçlarını karşılamak için nasıl sebze yetiştirileceği ve bu sebzelerin nasıl muhafaza edileceği bilgisinden de bahsedilmektedir (Şimşir, 2019).

$\mathrm{Bu}$ dersin verilmesi ile tarım toplumunda oldukça önemli bir role sahip kadının, bu alanda eğitilmesi amaçlanmıştır. Üçüncü sene verilmeye başlanan derste, toprağı tanımak, suyunu havasını sağlamak, ipek böceği beslemek, süt ineği bakımı, süt sağmak, süthaneler, sütçülük, peynirler, tavukçuluk üzerine eğitim verilecek, dördüncü sene ise kümes hayvanı, tavuk beslemek, bahçıvanlık, sebze bahçesi, meyve bahçesi, çiçek bahçesi, gülistan tesisi ve arı beslemek anlatılacaktır. 1919-1920 ders yılında programda Sanayi-i Ziraiye tatbiki için uygun yer bulunamadığından programdan kaldırılmıştı (Ceylan Dumanoğlu, 2019).

Dârülmuallimat'a, bazı Türk aydınları tarafından, öğretmen okulu olmanın ötesinde bir anlam yüklenmekte, “Memlekete münevver kadın yetiştirmeye çalışan bir müessese" olarak değerlendirilmektedir (Altın, 2019).

Cumhuriyet döneminde kadınlara ilişkin devrimlerin başarılı olmasında 1870'ten beri Dârülmuallimât'ın mezun vermekte oluşunun ve onların da pek çok kız ve kadını okutmuş olmasının önemli bir rolü olmuştur(Altın, 2019). 
"Sosyal ve ekonomik hayatta var olma mücadelesi veren son dönem Osmanlı kadınının girişimci bir birey olmasinı destekleyen ve kendisini geliştirmesine katkı sağlayan etkenler kadınlara yönelik yüksekögretim müfredatları bağlamında" inceleyen Özkul ve Baysal (2017) Osmanlı İmparatorluğu'nun son döneminde kadına yönelik yükseköğretim kurumlarının formal eğitimlerinde "girişimcilik kodları" tespit edildiğini bildirmektedir.

Bu çalışmada kitabın tanıtımı, içindeki bazı bilgilerin detaylı ve günümüz diliyle yazılmasıyla birlikte, özellikle un ve ekmek üzerine çalışan, geleneksel üretimle ilgilenen araştırıcıların da dikkatine sunulmakta ve bazı bilgilerin bugünle kıyaslanması amaçlanmaktadır.

\section{ESER İNCELEMESİ VE BULGULAR}

Tarım ve Orman Bakanlığı Kütüphanesinde bulunan 1915-1916 yıllarında basılmış olan "Kadınlara Amelî Sanayi-i Ziraiye Dersleri” adlı kitap; tarımsal alanda o güne kadar hazırlanan kitapların aksine, başlığında yer alan ifade ile, kadını eğitmenin toplumu eğitmek olacağı bilinciyle, kadınlara hitaben yazıldığı özellikle vurgulanmakta, ev idaresi ve ziraat sanatlarına ait bazı konuları içermesi açısından önem arz etmekle birlikte asıl onu önemli kılan, bu kitabın kadınlara yönelik olduğunun özellikle ön plana çıkarılmasıdır. "Maarrif-i Umumiye Nezareti Telif ve Tercüme Kütüphanesi” tarafindan, İstanbul'da Matbaa-i Âmire'de basılan kitaplardan ekmek kitabı 1331 yılında, gülyağı kitabı ise 1332 yılında basılmıştır. Miladi olarak 1915 ve 1916 yıllarına karşılık gelmektedir. Yani her halükarda, Osmanlı'nın bir yandan savaşlar, karışıklıklarla meşgul olup diğer taraftan da kadın eğitimine verdiği önemi yansıtması açısından önemlidir. İzmir meb'usu ve 'Dâr'ul Muallimat Sanayi-i Ziraiye Muallimi İhsan (İhsan Onnik Efendi)" tarafından kaleme alınmıştır. Darülmuallimat ders programına göre yazıldı ğ bildirilmekle, kız ögrretmen okullarında ders kitabı olarak okutulduğu anlaşılmaktadır (Bilir, 2020).

Ana konu başlıkları olarak "sütçülük, tereyağcılık, peynircilik, tavukçuluk, arıcılık, ipekçilik, ekmekçilik, nişastacılık, gül yağcılık, ve bahçıvanlik"'tan bahseder. Ev idaresinden ziyade tamamen teknik konular üzerinde durduğu görülmektedir. Kütüphanemizde elimize ulaşan kitap, serinin beşinci ve altıncı kitaplarının tek ciltte birleştirilmiş halidir. Itriyat, kokulu yağlar eldesi ile ilgili iki sayfalık bir takdimle başlamakta, devamında 23 sayfada gülyağcılık, 18 sayfada da ekmekçilik ve nişastacılık anlatılmaktadır.

Serinin beşinci cüz'ü olan 'Ekmek ve Nişastacılık San'atı" kitabında ilk olarak ekmek imalatı ele alınmıştır. Ekmeğin genellikle evlerde, kadınlar tarafından imal edildiğinden bahsedilerek, iyi bir ekmeğin nasıl yapılması gerektiği anlatılmaktadır. Ekmek terkibi verilirken, büyük kısmının buğday unundan olmakla beraber, m1sır, çavdar, arpa ve diğer hububat unlarının kullanıldı̆̆ı ancak diğerlerinin buğday unundan yapılan ekmek kadar nefasetli (lezzetli) olmadığ bildirilmektedir. Unun içeriği; gluten, nişasta, şeker, selüloz, mevadd-1 şahmiye (yağ) ve minerallerden ibarettir. Gıda olarak unun değerini artıran en önemli bileșenin gluten olduğu belirtilmiş, unun içeriği Çizelge 1'de verilmiştir. Be- 


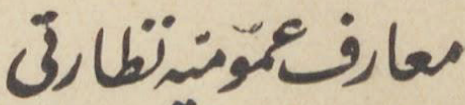 كأليف ونزبه كتبنانهي \\ ₹人:}

قادينلره

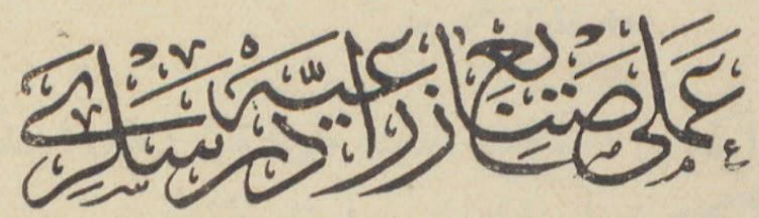

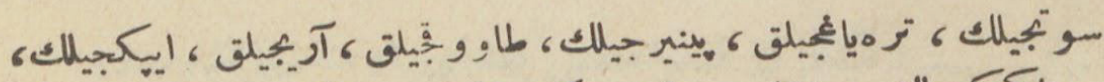

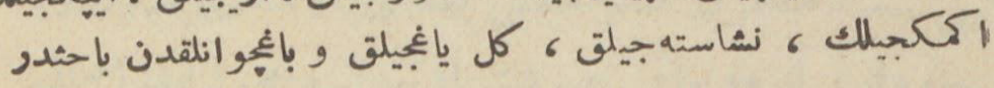

$$
\begin{aligned}
& \text { م: : }
\end{aligned}
$$

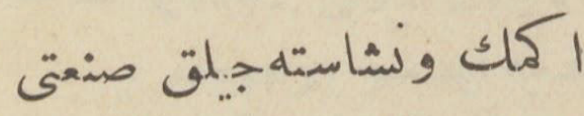

$$
\begin{aligned}
& \text { عردى : }
\end{aligned}
$$

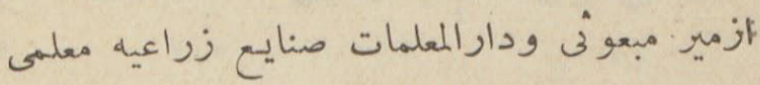

$$
\begin{aligned}
& \text { ' } \\
& \text { دارالمجلمات درس vووغراملرينه كوره يازلمشدر } \\
& \text {-10. }
\end{aligned}
$$

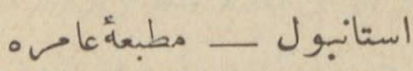

$$
\begin{aligned}
& 18<1
\end{aligned}
$$

Resim 1. Ekmek ve Nişastacılık San’atı kitabının kapak sayfası 
Çizelge 1. Muhtelif Unların yüzde hesabıyla vasatî terkibleri (Unun içeriği (\%))

\begin{tabular}{|l|r|r|r|r|}
\hline & Buğday unu & Çavdar unu & Misır unu & Arpa unu \\
\hline $\mathrm{Su}$ & 14 & 15 & 7,5 & 13,5 \\
\hline Gluten & 12 & 11 & 15 & 13,5 \\
\hline Nişasta-Şeker & 71,5 & 69,5 & 71 & 67 \\
\hline Selüloz & 0,5 & 1 & 2 & 1 \\
\hline $\begin{array}{l}\text { Mevadd-1 şahmiye (yağlı } \\
\text { maddeler) }\end{array}$ & 1 & 2 & 3,5 & 1 \\
\hline $\begin{array}{l}\text { Mevadd-1 madeniye (mineral } \\
\text { maddeler) }\end{array}$ & 1 & 1,5 & 1 & 2 \\
\hline & 100 & 100 & 100 & \\
\hline
\end{tabular}

yaz ekmek eldesi için glutenin önemli bir kısm1nın mümkün olduğu ölçüde undan ayrılmasının gerektiği önerilmektedir. Her ne kadar buradaki cümle "Undan mümkün mertebe beyaz bir ekmek elde etmek içün glutenin kısm-ı âzamını ayırmak lâzımdır." şeklinde ifade edilmişse de buradaki kast edilenin gluten yerine kepek olabileceği düşünülmektedir. Köy ekmeğinin bu sebeple biraz daha esmer olduğu ama beyaz ekmeğe göre hazmının daha zor olduğu bildirilmektedir (Ekmek ve Nişastacılık San'atı, s.2).

Ekmek imalatında yoğurma, kabartma, ekşitme ve pişirme safhaları anlatılmaktadır. Ekmek fabrikalarında özel hamur yoğurma makinalarının kullanıldığından bahsedilmektedir. Evlerde ekşi maya ile (bugün de olduğu gibi) ekmek yapılırken, ekmek fabrikalarında "sabun kalıbı şeklinde ve katı kıvamda olan" özel bir mayanın kullanıldığı, bu mayalar ile yapılan ekmeklerin daha nefis olduğu bildirilmektedir(Ekmek ve Nişastac1lik San'at1, s.7-8).

"Elde ekmek mayası bulunmadığ vakit, yeniden maya tedarik etmek içün: Bir mikdar un ılık suyla yoğurulub hamur haline konulduktan sonra

Çizelge 2. Beyaz ve siyah ekmeğin içeriği (\%)

\begin{tabular}{|l|r|r|}
\hline & Beyaz ekmek & Siyah ekmek \\
\hline $\mathrm{Su}$ & 30 & 31 \\
\hline Gluten & 7,80 & 10 \\
\hline Nişasta-Şeker & 60 & 57 \\
\hline Selüloz & 0,4 & 0,8 \\
\hline Yağlar & 0,3 & 0,7 \\
\hline Mineral maddeler & 1,5 & 10,5 \\
\hline & 100 & 100 \\
\hline
\end{tabular}


Çizelge 3. Bazı hububat ile patatesin havi oldukları niş'anın miktarı

\begin{tabular}{|l|r|}
\hline İsm-i nebatat & Havi oldukları niş'a yüzde \\
\hline Buğday & $50-56$ \\
\hline Buğday unu & $57-67$ \\
\hline Arpa & $68-69$ \\
\hline Arpa unu & $64-65$ \\
\hline Misır & $67-75$ \\
\hline Misır unu & $77-78$ \\
\hline Pirinç & $80-85$ \\
\hline Patates & $18-20$ \\
\hline
\end{tabular}

5-6 saat kadar 25-30 derece hararetinde bulunan bir mahalde birakmalıdır. Havadaki ekmek hamîrelerinin te siri ile hamur yavaş yavaş ekşiyerek hoş bir koku alır. İşbu maya, ekmek mayası makamında kullanılur." (Ekmek ve Nişastacılık San'at1, s.7-8).
"Mayalanma safhası yaklaşık 1 saat sürer. El ile hamurun üzerine basılıp kaldırıldiğında hamur tekrar geri eski halini almasi ve hamurun güzel koku vermesinden firına atılacak zamanin geldiği anlaşılır. $1 \mathrm{~kg}$ ekmek elde etmek için yaklaşık 1600 gram hamur tartmak gerekmektedir. Ekmeğin pişerken iyice kabarması için $300{ }^{\circ} \mathrm{C}$

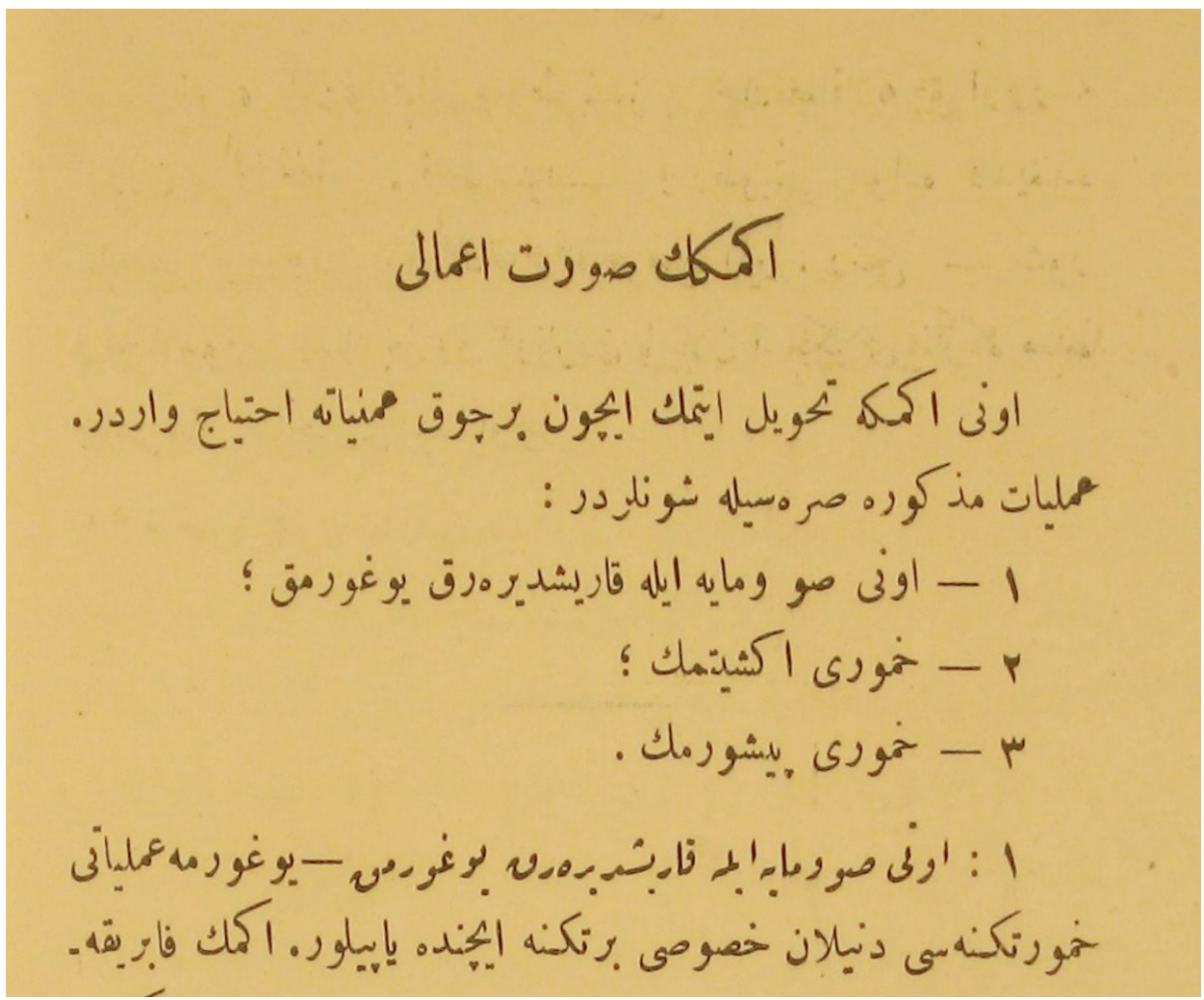

Resim 2: Kitaptan ekmek yapımı ile ilgili bir bölüm 
sicakllktaki firında ortalama bir buçuk iki saat kalması gerekmektedir. Fırının içine su dolu bir kap konulmasl veya islak bir bezle firın zemininin silinmesi halinde ekmeğin kabuğu yanmaz, daha yumuşak olur. Hamur firında pişerken hacmi yaklaşık olarak dörtte bir oranında artar. $F_{l}$ rından çıkarılınca bir müddet açık havada soğutulur." Verilen ilginç bir bilgi de şudur: "Pişmiş ve manzaralı göstermek için hamur yoğurulurken bir miktar göztaşı atılır." Bölümün sonunda beyaz ve siyah ekmeğin terkibi verilmiştir (Çizelge 2) (Ekmek ve Nişastacılık San'atı, s.8-10). Kitapta önce siyah ekmek, sonra beyaz ekmek içeriği verilmiştir. Bir önceki bölümde beyaz ekmeğin elde edilişinden bahsettiği yani önce normal un daha sonra ondan bazı maddelerin ayrılarak beyaz ekmek yapıldığı anlatımı dikkate alındığında, siyah ekmek olarak kastedilenin aslında kepeği ayrılmamış olan esmer ekmek olduğu düşünülmektedir.
Kitapta ikinci olarak nişastacılık ele alınmaktadır. Nişasta; "bazı nebâtâtın muhtelif aksamından çıkarılan bir madde" olarak tanımlanmakta, buğday, arpa, mısır, pirinç, bakliyattan bakla, fasülye, mercimek, patates, yer elması, kestane, meşe palamudunda bulunduğu, aralarında içerik olarak fark olmamakla birlikte bazı özellikleri bakımından farklılık gösterdiği bildirilmektedir (Çizelge 3) Ekmek ve Nişastacılık San'atı, s.12$13)$.

Buğdaydan nişastanın çıkarılması için iki usul bulunmaktadır: Birincisi eski usul yahud ihtimar usulü, ikincisi de yeni usul yahud ihtimar içermeyen usuldür. Kelime anlamı mayalanma olan ihtimar usulünde; buğday güzelce temizlenip bir iki gün temiz suda bekletilir. Şişen ve yumuşayan buğdaylar bulgur değirmeninde ezilir ve bir fiçıya alınarak üzerine su doldurulur. Elde varsa daha önceden mayalanmış biraz

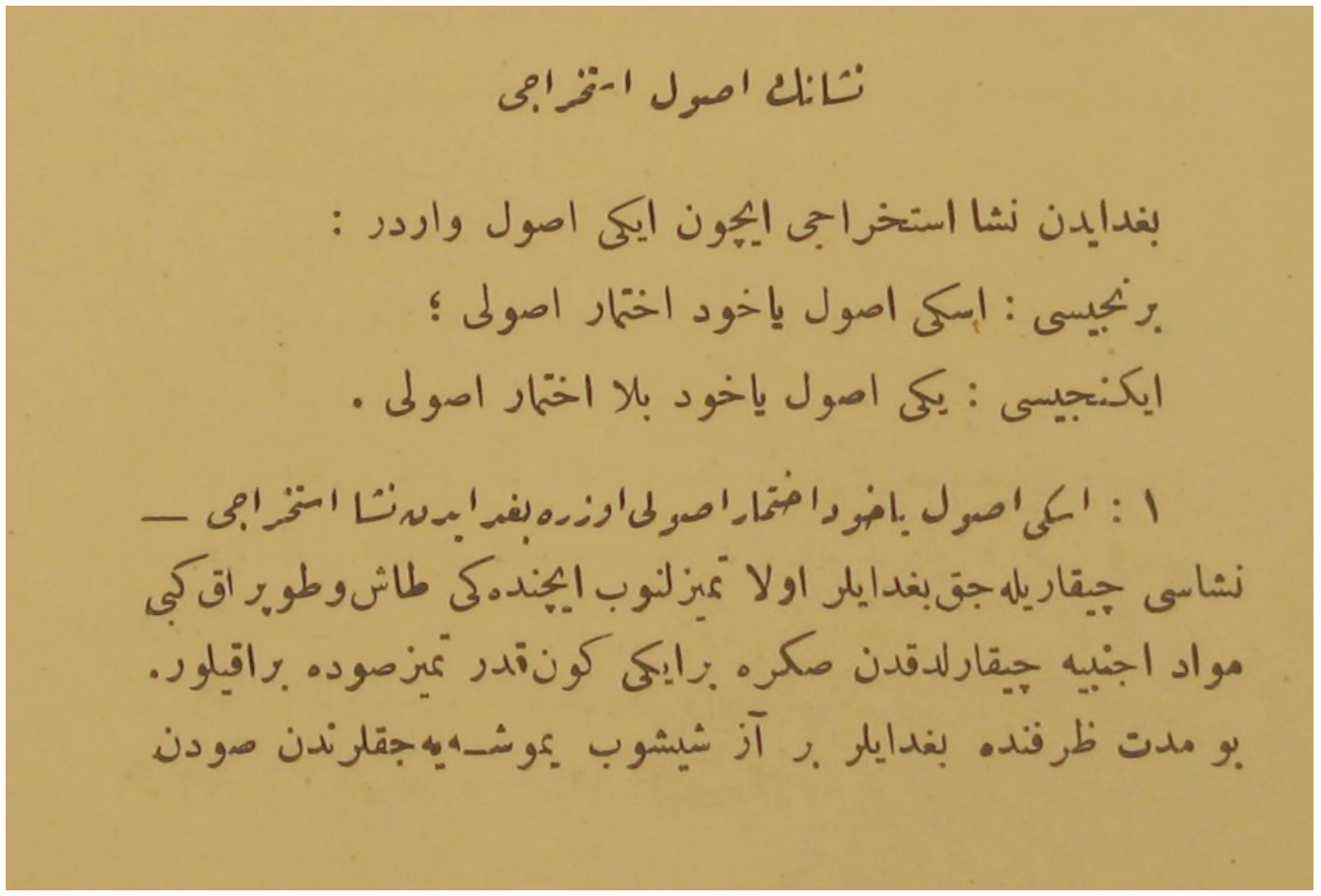

Resim 3: Kitaptan nişastanın elde edilmesi ile ilgili bir bölüm 
nişasta, yoksa sulandırılmış ekmek mayası ilave edilerek ekşimek üzere bırakılır. Mayalanma başlayınca ispirto veya sirke kokuları gelmeye başlar. Bu esnada glutenin bir kısmı parçalanır. Daha sonra amonyak oluşumu başlar, fiçıdan pis bir koku gelir. Mayalanmanın iyi bir şekilde gerçekleşmesi için ara sıra karıştırmak gerekir. Kokular azaldığında, su berraklaştığında ve buğday iki parmak arasına alınıp yoğurulduğunda beyaz renkte niş’anın çıktığı görüldüğünde mayalanma tamamlanmış demektir. Havanın sicaklığ , kullanılan mayanın cinsi ve miktarına göre 10-15 gün hatta daha fazla sürebilir. Bu hale gelmiş buğdayın üstündeki ekşimiş su başka bir kaba boşaltılır. Kalan malzeme bez bir torbaya konur, ara sira üzerine temiz su dökülmek suretiyle bir tekne içerisinde üzerine baskı uygulanarak yoğrulur. Torbadan berrak su akıncaya kadar bu işleme devam edilir. Bu suretle elde edilen nişa sütü ince kıl ya da ipek kalburdan geçirilir, süzülür ve büyük bir kaba doldurulur ve bir süre kendi haline birakılır. Bir süre sonra nişanın kabın altında birikir. Sifonla üstteki su alınır, kalan nişa içine bez serilmiş sepetlere doldurularak havadar bir yerde bir müddet birakılır, sonra geniş kaplara alınarak güneşte kurutulur (Ekmek ve Nişastacılık San'at1, s.14-15).

Mayalanma olmaksızın nişasta eldesinde ise; buğday temizlenir, fiçıya konur, üzerine su doldurulur ve mayalanmaya meydan vermemek için birkaç kez su değiştirilir. Birkaç gün sonra, daneler iyice şişip iki parmak arasına alındığında ezilecek şekilde yumuşadığında kalburla alınır, iki taş arasında ezilir, yoğurulur ve bu esnada üzerine su dökülür. Bir miktar gluten ve selüloz da içeren nişa elde edilmiş olur. kalburdan geçirilir. Su ile kalburdan geçirilen niş'a sütü bir kaba alınır, dinlendirilir. Bu esnada niş'a kabın en alt kismında kalır, üstünde de daha esmer renkli diğer maddeler birikir. Bu esmer tabaka alınıp, alttaki nişa tabakasının üstüne su doldurulur, karlştırllır ve tekrar dinlenmeye birakılır. Aynı işlem, üstte yabancı maddeler içeren tabaka oluşmayıncaya, temizleninceye kadar tekrarlanır. Bundan sonraki işlem, mayalı sistemdeki gibidir (Ekmek ve Nişastacılık San'atı, s.16-17). Bunların yanında, kepeğinden ayrılmış undan da kolaylıkla nişasta elde edilebildiği bildirilmektedir. Niş’anın pelte, güllaç, muhallebi gibi gida olarak kullanılmasının yanında sanayide kumaş kolalama, kağıt yapıştırmak, evlerde çamaşır kolalama, pudra imal etme gibi başka amaçlarla da kullanıldığı, cilt hastalıklarında niş’a banyosu önerildiği bildirilmektedir Ekmek ve Nişastac1lik San'at1, s.18).

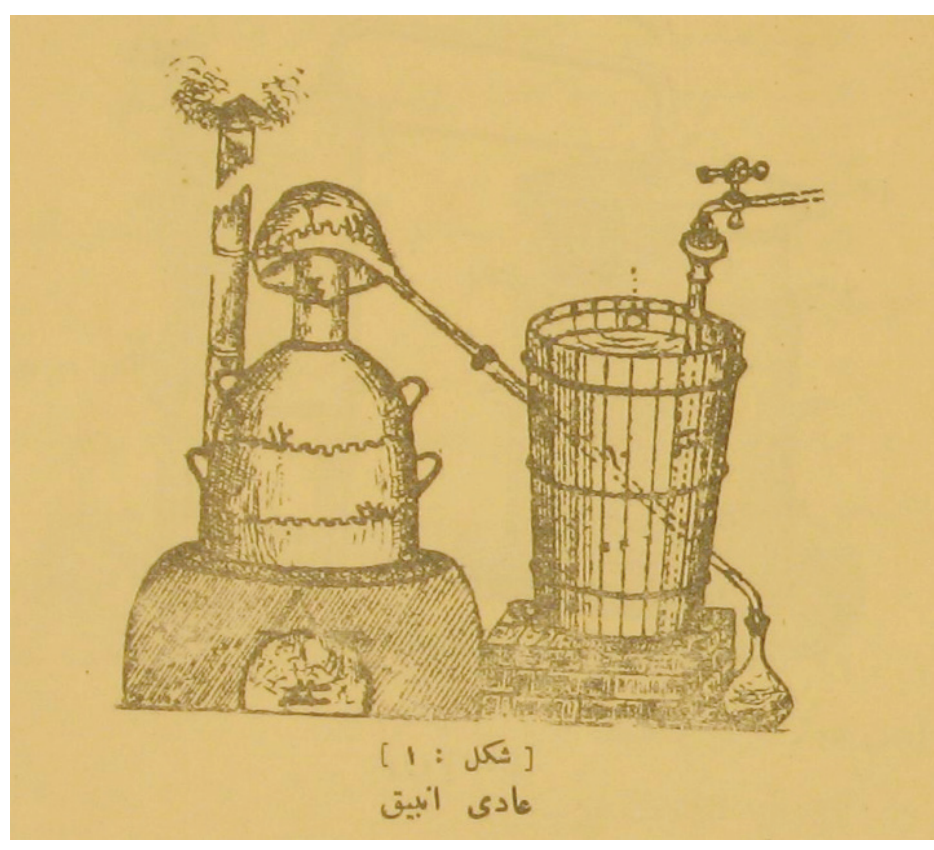

Resim 4: Gülyağcılık kitabından: Âdi imbik 


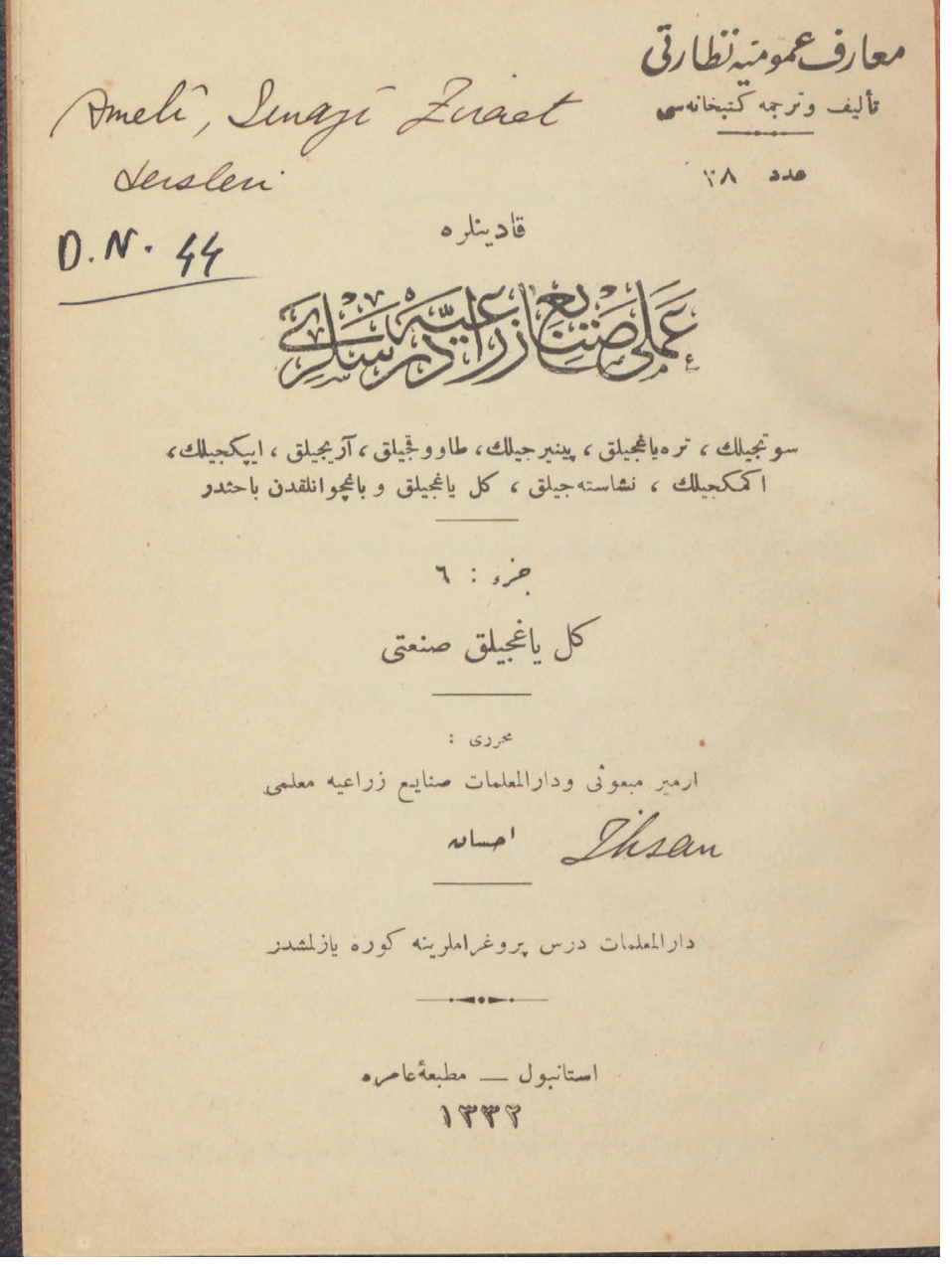

Resim 5. Gülyağcılık kitabının kapak sayfası

Serinin altıncı kitabı olan "Gülyağcılık" bölümünde gül bahçesi tesisi, gül çiçeklerinin toplanması, gülyağı elde etme usulleri, yağhaneler, kazan, imbikler, imbik külahı, soğutucular, şişeler, toplama hunileri, bunların nasıl kullanılacakları, gül yağının kalite özellikleri, rengi, kokusu, keskinliği, derecesi, sıcaklık değeri gibi konulardan bahsedilmektedir.

\section{SONUÇ}

Kitapta ekmek ile ilgili özellikle selüloz, gluten, beyaz-esmer ekmeğin farklarından bahisle, beyaz ekmek önermeleri, zamanla değişmekle, selüloz içeriğinin hem besleyici hem tok tutucu hem de diyabetik hastalarda sağlık açısından önemi bugün farklı değerlendirilmekle beraber, ekmek yapımı ve nişasta eldesinde Anadolu'da hala bu yöntemlerin kullanılmakta olduğu görülmektedir.

Gülyağı eldesi ile ilgili bölümde kullanılan malzemeler ve yöntem de hala kullanılagelen yöntem ve malzemelerdir. Malzemelerin resimlerle izahı da ayrıca önem arzetmektedir.

Hem gülyağı ve hem de ekmeğin ve nişastanın üretimi-eldesi ve kullanımı ile ilgili tarihsel bir doküman olmasının yanında, bu bilgilerin kadınlara yönelik olarak hazırlandığının vurgulanmas1 ve zirai ilimler kapsamında sunulmuş olması, bunların öğretmen okullarında ders kitabı olarak okutulması, doğru bilgilerin yayılması, yaygınlaştırılması açısından oldukça önemlidir. Savaş, isyanlar, karışıklıklar, toprak kayıplarının yanında kadınların önemsenmesi, imkansızlıklar esnasında kadınlara yönelik eğitim programları ve o programlara göre kitap hazırlanmış olması Osmanlı'da kadına verilen önemi göstermektedir.

\section{KAYNAKÇA}

Aksoy, Y. (2017). Osmanlı Devleti'nde k1z öğretmen okulları (Darülmuallimat) ve kadının meslek hayatına katılması (18701920), Yüksek Lisans Tezi, Pamukkale 
Üniversitesi Sosyal Bilimler Enstitüsü Tarih Anabilim Dalı, Denizli.

Altın, H. (2017). Osmanlı Eğitim Tarihinden Dârulmuallimat (Açılışı ve Gelişim Süreci). Akademik Matbuat, 1 (1), 21-37

Bilir, M. (2020). Osmanlı'da kadınlara yönelik zirai eğitimler, Türk Tarım Orman Dergisi, 258, 94-95.

Ceylan Dumanoğlu, H. (2019). Osmanlı Devleti'nde k1z öğretmen okulu Darülmuallimat (1870-1924), Doktora Tezi, Kahramanmaraş Sütçü İmam Üniversitesi / Sosyal Bilimler Enstitüsü Tarih Anabilim Dal1, Kahramanmaraş.

İhsan, (1331). Kadınlara Amelî Sanayi-i Ziraiye Dersleri - Ekmek ve Nişastacılık San'at1, Maarrif-i Umumiye Nezareti Telif ve Tercüme Kütüphanesi, Matbaa-yı Âmire, İstanbul.

İhsan, (1332). Kadınlara Amelî Sanayi-i Ziraiye Dersleri - Gülyağcılık San'atı, Maarrif-i Umumiye Nezareti Telif ve Tercüme Kütüphanesi, Matbaa-i Âmire, İstanbul.

Özkul, A , Baysal, H . (2017). Son Dönem Osmanlı Kadın Yükseköğretiminde Girişimcilik Kodları: Ticâret Mekteb-i Âlîsi, İnas Dârülfünûnu ve Dârülmuallimât. Süleyman Demirel Üniversitesi Fen-Edebiyat Fakültesi Sosyal Bilimler Dergisi, (41), 1-20.

Şanal, M. (2004). Osmanlı İmparatorluğu'nda K1z Öğretmen Okulunda Görev Yapan Kadın İdareci ve Öğretmenler ile Okuttukları Dersler, Belleten, c. LXVIII, S. 253.

Şimşir, A. (2019). Darülmuallimat eğitim programı ve bir Darülmuallimat öğretmeni olarak Ahmet Mithat Efendi. Yüksek Lisans Tezi, İhsan Doğramac1 Bilkent Üniversitesi / Eğitim Bilimleri Enstitüsü / Eğitim Programları ve Öğretimi Anabilim Dalı, Ankara Tunç Yaşar, F . (2019). Geç Dönem Osmanlı Kız Mekteplerinde Fennî Ev İdaresi Eğitimi: Müfredat ve Ders Kitapları. Journal of Turkology, 29 (2), 591-620.

Elektronik Kaynaklar-Sözlükler-Diğer Kaynaklar:

https://www.lexiqamus.com/tr

https://www.luggat.com/

https://katalog.marmara.edu.tr/eyayin/pdf/ F03115.pdf

http://ktp.isam.org.tr/risaleosm/

https://kutuphane.aku.edu.tr/kutuphane/nadire$\underline{\text { serler }}$

https://kutuphane.tarimorman.gov.tr

Dârülmuallimîn ve Dârülmuallimât Nizamnâmesi, 1331.

Dârülmuallimîn ve Dârülmuallimât-1 İbtidâiye Talimatnâmesi, 1332. 